\title{
Characterizing heat stress on livestock using the temperature humidity index (THI)—prospects for a warmer Caribbean
}

\author{
Cicero H. O. Lallo ${ }^{1} \cdot$ Jane Cohen $^{2} \cdot$ Dale Rankine $^{3} \cdot$ Michael Taylor $^{3} \cdot$ Jayaka Cambell $^{3} \cdot$ Tannecia Stephenson $^{3}$
}

Received: 3 September 2017 / Accepted: 8 May 2018 / Published online: 24 May 2018

(C) The Author(s) 2018

\begin{abstract}
There is an urgent need to mitigate climate change-induced heat stress in livestock and poultry in the Caribbean, given the deleterious effects it has on food and nutrition security. The temperature humidity index (THI) was used to assess the potential for heat stress on four types of livestock and poultry (broiler and layer chickens, pigs and ruminants) for three different agroecological locations in Jamaica. The THI was formulated specifically to each livestock type and was examined for 2001-2012 for seasonal and annual patterns of variability. Differences in THI were observed between summer (July to September) and winter (December to February) with some moderation due to agro-ecological location. Our results suggest that animals in ambient field conditions in Jamaica may already be experiencing considerable periods of heat stress even during the relatively cooler northern hemisphere winter months. Future patterns of heat stress relative to a 1961-1990 baseline were derived from a regional climate model when mean global surface air temperature is $1.5,2.0$ and $2.5^{\circ} \mathrm{C}$ above pre-industrial levels. At $1.5^{\circ} \mathrm{C}$, marked increases were noted in THI and almost persistent year-round heat stress is projected for Caribbean livestock. Conditions will be exacerbated at the higher global warming states. Possible response strategies such as cooling technologies are discussed.
\end{abstract}

Keywords Jamaica $\cdot$ Livestock $\cdot$ Climate change $\cdot$ Temperature humidity index (THI)

\section{Introduction}

The Intergovernmental Panel on Climate Change (IPCC) regards small island states, including those constituting the Caribbean, as among the most vulnerable to climate change (Nurse et al. 2014). Among the climatic changes already seen in the Caribbean has been an increase in surface temperatures. Jones et al. (2015) reported statistically significant warming everywhere in the Caribbean for the periods 1901-2012, 1951-2012 and for over half the region during 1979-2012. Stephenson et al. (2014) showed statistically significant

Dale Rankine

rankinedr@gmail.com

Cicero H. O. Lallo

massala101@gmail.com

Jane Cohen

jane.cohen@uwimona.edu.jm

Michael Taylor

michael.taylor@uwimona.edu.jm

Jayaka Cambell

jayaka.campbel102@uwimona.edu.jm warming between 1961-2010 and 1986-2010 using regional station data. They also found a stronger warming trend for minimum temperature than maximum temperature; an increase in the frequency of warm days, warm nights and extreme high temperatures; and a decrease in cool days, cool nights and extreme low temperatures. Warming trends have also been identified in maximum, mean and minimum temperatures for Jamaica - the country of focus for this paper (CSGM 2017).

Modelling studies focused on the Caribbean region have shown that irrespective of model or scenario, temperatures

Tannecia Stephenson

tannecia.stephenson02@uwimona.edu.jm

1 Open Tropical Forage and Animal-Production Laboratory, Department of Food Production, The University of The West Indies, St. Augustine, Trinidad and Tobago

2 Department of Life Sciences, The University of The West Indies, Mona Campus, Kingston, Jamaica

Department of Physics, The University of The West Indies, Mona Campus, Kingston, Jamaica 
will continue to increase until the end of the current century. Further, studies from the Coupled Model Intercomparison Project Phase 3 (CMIP3) models have projected increases of between 1.0 and $3.5^{\circ} \mathrm{C}$ by the end of the century, with $95 \%$ of all days exceeding the 90th percentile of current temperatures (Campbell et al. 2011; McSweeney et al. 2012; Karmalkar et al. 2013). Taylor et al. (2018), using CMIP5 models and the Representative Concentration Pathway (RCP) scenario RCP4.5, have shown that when the global mean surface temperature reaches $1.5^{\circ} \mathrm{C}\left(2.0^{\circ} \mathrm{C}\right)$ above pre-industrial levels, the Caribbean will be warmer than at present (using a 19712000 baseline) by between 0.5 and $1.0^{\circ} \mathrm{C}\left(1.0\right.$ and $\left.2.0^{\circ} \mathrm{C}\right)$.

Increasing temperatures have significant and adverse implications for livestock productivity. Among other things, they affect the ability of the animals to thermoregulate (DeShazer et al. 2009). Studies on cattle have shown that increasing temperatures resulted in decreases in voluntary intake of food, weight, fertility and milk production (Armstrong 1994; Frank et al. 2001; Kadzere et al. 2002; Amundson et al. 2006; Ben Salem and Bouraoui 2009; Hernández et al. 2011; Gantner et al. 2012). Other studies have reported heat stress-induced decreases in poultry egg production and quality (Mashaly et al. 2004; Ajakaiye et al. 2011) and broiler productivity (Abu-Dieyeh 2006; Lin et al. 2006; Daghir 2008), as well as adverse impacts on production in goats ( $\mathrm{Lu}$ 1989; Lallo et al. 2012; Salama et al. 2014) and sheep (Marai et al. 2007). Although these livestock are an important part of the agricultural sector in the Caribbean (Jennings 2006), there has been little work done on the potential impact of climate change and specifically of increasing temperatures.

Indices used to measure heat stress include the temperature humidity index (THI), Black Globe-Humidity Index (Buffington et al. 1981), Heat Load Index and the Respiratory Rate Predictor (Silva et al. 2007). The THI has proven a useful tool to gauge livestock productivity response as a function of climate (Ravagnolo et al. 2000; Hahn et al. 2003; Silva et al. 2007; Dikmen and Hansen 2009; Marai and Habeeb 2010). It is based on air temperature and relative humidity $(\mathrm{RH})$ with different weightings for different species (Hahn et al. 2009) and is an indicative measure of "the sum of forces external to the animal that acts to displace body temperature from its set point' (Dikmen and Hansen 2009). Variations in THI formulation sometimes add a term for air velocity to account for the cooling effect of air movements (Tao and Xin 2003) or terms for both wind speed and solar radiation (Mader et al. 2006). The comparative usefulness of various THI formulations has been examined using animals' physiological state by several authors including Silva et al. (2007) for Brazil and Bohmanova et al. (2007) and Dikmen and Hansen (2009) for the southern USA.

Notwithstanding extensive research done elsewhere, there is a lack of studies examining THI values for environmental conditions in the Caribbean and relating them to potential heat stress conditions for animals. Lallo et al. (2017) studied THI in relation to grazing time of ruminants, the Barbados Blackbelly (BB) hair sheep in Trinidad. They found that THI values ranged from 70.0 to 83.6 and suggested that the sheep came under heat stress. In an earlier study, Lallo et al. (2012) found that air temperatures in an open-sided, naturally ventilated broiler house at the Field Station of the University of the West Indies Trinidad, were between 26.2 and $27.8^{\circ} \mathrm{C}$ in the morning and rose to 27.1 to 29.0 in the late afternoon. Though not specifically determining THI, they noted that the temperatures were considerably higher than the thermoneutral zone of 18 to $24{ }^{\circ} \mathrm{C}$ proposed for tropical regions (Holik 2009). Ajakaiye et al. (2011) observed high daytime THI values in Cuba, with a mean of 85.5 (sd 4.06).

In this paper, heat stress conditions were determined using THI calculations for four categories of livestock and poultry-poultry (layers and broilers), ruminants (dairy) and pigs - across three agro-ecological zones in Jamaica, with meteorological data for the period 2001-2012. The livestock species examined are of significance to the (protein) food and nutrition security for Jamaica and the wider Caribbean (FAO 2015). With only two important ruminants in Jamaica, cattle are produced for beef and milk and goats for meat, although there is considerable potential for dairy goat production (CARDI 2013). Future heat stress was also determined from THI using data from multiple runs of a regional climate model when global mean surface air temperatures are projected to be $1.5,2.0$ and $2.5^{\circ} \mathrm{C}$ above pre-industrial levels. The Caribbean has advocated for keeping global warming to $1.5^{\circ} \mathrm{C}$ or below by the end of the century (Benjamin and Thomas 2016). The changes in THI were used to indicate the potential threat to livestock production in the Caribbean as a result of altered environmental conditions from different levels of global warming.

\section{Data and methodology}

\section{Climate data}

\section{Historical data}

Daily observed meteorological data for 2001 to 2012 were obtained from the Meteorological Service of Jamaica for three locations in Jamaica: Bodles Research Station (Old Harbour, St. Catherine) in south central Jamaica, Norman Manley International Airport (Kingston) in south-eastern Jamaica and Sangster International Airport (Montego Bay, St. James) in north-western Jamaica (see Table 1). Daily values for maximum and minimum temperature measurements and relative humidity (RH hereafter, measured at 1300 and 1900 UTC) were used to determine mean values for each variable per month. 
Table 1 Location and mean climate at three study sites representing different agro-ecological locations in Jamaica

\begin{tabular}{|c|c|c|c|}
\hline Parameter & $\begin{array}{l}\text { Norman Manley International } \\
\text { Airport, Kingston }\end{array}$ & $\begin{array}{l}\text { Sangster International } \\
\text { Airport, Montego Bay }\end{array}$ & $\begin{array}{l}\text { Bodles Research Station, } \\
\text { St Catherine }\end{array}$ \\
\hline Coordinates & $\begin{array}{l}\text { Latitude: } 17^{\circ} 56^{\prime} 03^{\prime \prime} \text {; } \\
\quad \text { longitude: } 76^{\circ} 46^{\prime} 45^{\prime \prime}\end{array}$ & $\begin{array}{l}\text { Latitude: } 18^{\circ} 29^{\prime} 51^{\prime \prime} \text {; } \\
\quad \text { longitude: } 77^{\circ} 55^{\prime} 09^{\prime \prime}\end{array}$ & $\begin{array}{l}\text { Latitude: } 17^{\circ} 55^{\prime} 47^{\prime \prime} ; \\
\quad \text { longitude: } 76^{\circ} 08^{\prime} 03^{\prime \prime}\end{array}$ \\
\hline Height above sea level (m) & 2.7 & 9.0 & 29 \\
\hline Average monthly rainfall range $(\mathrm{mm})(1971-2000)$ & $21-143$ & $52-161$ & $34-159$ \\
\hline Average annual maximum temperature range $\left({ }^{\circ} \mathrm{C}\right)(1992-2011)$ & $30.9-33.1$ & $29.5-33.2$ & $30.7-33.9$ \\
\hline Average annual minimum temperature range $\left({ }^{\circ} \mathrm{C}\right)(1992-2011)$ & $22.9-26.0$ & $21.9-24.7$ & $18.7-23.0$ \\
\hline Average relative humidity range (\%) (2001-2011) ${ }^{\mathrm{a}}$ & $66.4-82.0$ & $70.9-84.7$ & $68.8-87.2$ \\
\hline
\end{tabular}

${ }^{a}$ Average monthly relative humidity is calculated as the mean of that at 1300 and 1900 UTC (using monthly means based on daily measurements) and the range determined over the period January 2001 to December 2011 (available for all sites only from 2001)

\section{Model data}

Future climate data were obtained from the Providing REgional Climates for Impact Studies (PRECIS) regional climate modelling system (RCM) (Jones et al. 2003, 2004) which has been successfully used in the Caribbean (Campbell et al. 2011). The data have a spatial resolution of $25 \mathrm{~km}$ and were extracted for the grid-boxes in which the three agro-ecological locations fell. In an ongoing dynamical downscaling initiative in the Caribbean (Taylor et al. 2013), PRECIS is being driven by a subset of the 17 -member Quantifying Uncertainty in Model Predictions (QUMP) ensemble of the Hadley Centre Coupled Model, version 3 (HadCM3) global climate model (Murphy et al. 2007) run using the AIB SRES Scenario (IPCC 2000). The QUMP data were acquired from the KNMI climate explorer database (https://climexp.knmi.nl) and PRECIS simulations span 1850-2100. A validation methodology outlined by McSweeney et al. (2012) was used to identify the subset of QUMP runs being downscaled for the Caribbean. Four of a possible six completed PRECIS downscaled QUMP simulations were available for use in this study.

To determine the future climate at global warming thresholds of $1.5,2.0$ and $2.5^{\circ} \mathrm{C}$ above pre-industrial values, a timesampling approach similar to that used by Taylor et al. (2018) in their study of the Caribbean was followed. A 10-year running mean was applied to the time series of global mean surface air temperature anomalies derived for each of the driving GCM QUMP runs, where anomalies were with respect to the pre-industrial period taken as 1860-1900. The first year at which the respective global warming threshold was achieved with all subsequent running mean values being higher was identified. A 21-year daily time series centred on each global target year was extracted for each variable of interest and for each QUMP-driven PRECIS simulation. PRECIS data for 1961-1990 (baseline) were also extracted for each of the four ensemble members. The variables extracted were RH and $2 \mathrm{~m}$ maximum and minimum temperature.

\section{Methodology}

\section{Calculation of temperature humidity index}

THI was used in this study to examine heat stress conditions for Caribbean livestock and poultry due to its relative simplicity and the availability of the meteorological data used in its formulation. The weather parameters used in its calculation, temperature and $\mathrm{RH}$, are more readily available than other parameters needed to calculate other indices.

THI thresholds have long been used by US extension services to alert livestock producers of potential weather-based heat stress (Whittier 1993; Eirich et al. 2015), e.g. the Livestock Weather Safety Index (NOAA 1976). Hahn et al. (2009) quote the following THI based stress ranges for ruminants: normal $\leq 74$; moderate $75-78$; severe $79-83$; very severe (emergency) $\geq 84$. The corresponding values for non-sweating animals such as poultry and pigs are as follows: normal $<27.8$, moderate 27.8-28.8, severe 28.9-29.9 and very severe (emergency) $\geq 30.0$ (Marai et al. 2001).

The THI formulations chosen were adapted from Tao and Xin (2003) for broilers, Zulovich and DeShazer (1990) for layers, NRC (1971) for ruminants and Zumbach et al. (2008) for pigs. In these indices, temperature is accounted for by dry bulb measurements and RH by wet bulb temperature (poultry) or RH itself (ruminants and pigs); measurements are timed according to research objectives. In order to assess the greatest likely heat stress, maximum daily temperature $\left(T_{\max }\right)$ was used for the dry bulb values. Another reason for using $T_{\max }$ was the absence of measurements for wet bulb temperature $\left(T_{\mathrm{wb}}\right)$ in both historical and future data sets. In taking $T_{\max }$ as $T_{\mathrm{db}}$, minimum daily temperature $\left(T_{\min }\right)$ could be used instead of $T_{\mathrm{wb}}$ for the poultry indices. The impact of making this substitution was tested by deriving $T_{\mathrm{wb}}$ values (according to Stull 2011, using $T_{\max }$ and $\mathrm{RH}$ ) and comparing THI values calculated with the derived $T_{\mathrm{wb}}$ against those calculated with 
$T_{\min }$. The THI formulae used are shown below, with temperatures in degrees Celsius and RH expressed as percentage.

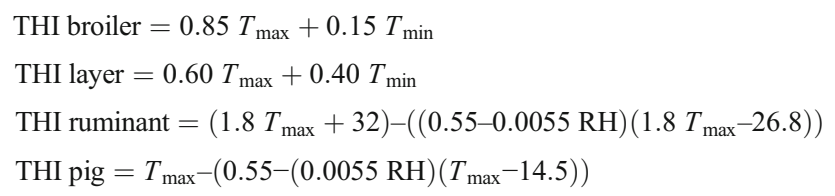

\section{Statistical analysis}

Historical trends in THI values were investigated separately for the four types of livestock and poultry. The variability of observed monthly THI values for 2001 to 2012 was depicted in box plots, and means were compared using analysis of variance (ANOVA) for months and locations (using the 12 annual values as replicates). Seasonal variations were also highlighted. Although seasons in Jamaica are primarily determined by rainfall, since temperature is the most important factor in heat stress, the 'seasons' considered in this study are 'winter' (December to February) and 'summer' (July to September), corresponding respectively to the climatological coolest and warmest months. For the climate model-derived THI, values were calculated for each of the four-member ensemble at each global warming target and then averaged. The future changes in THI at $1.5,2.0$ and $2.5{ }^{\circ} \mathrm{C}$ were expressed as the difference from the model-derived THI values of the baseline period (1961-1990) for the multi-model ensemble.

\section{Results}

\section{Substitution in temperature humidity index formulation for poultry}

The substitution of $T_{\min }$ for $T_{\mathrm{wb}}$ resulted in slight underestimation of THI values, since $T_{\min }$ was proportionately lower than the corresponding, derived $T_{\mathrm{wb}}$. For the historical data, the reduction in THI values was $2-4 \%$ for broilers and 5-9\% for layers, the difference in the ranges reflecting the different weighting of $T_{\mathrm{wb}}$ in the THI formulation, it being lower for broilers $(0.15)$ than for layers (0.40). Across locations, the linear correlation between the two versions of THI was high: $R^{2}=0.97-$ 0.99 for broilers and $R^{2}=0.83-0.97$ for layers. There were similar but smaller differences between THI values calculated with $T_{\max }$ and $T_{\min }$ versus $T_{\max }$ and $T_{\mathrm{wb}}$ for modelled data from the PRECIS QUMP experiments: a reduction in THI of $1-3 \%$ for broilers and $3-7 \%$ for layers. Again, the linear correlation was strong, with $R^{2}$ values of 0.99 for broiler THI and 0.98 for layer THI.

\section{Historical analysis}

The monthly range in THI values for each type of livestock (averaged over the three locations) between 2001 and 2012 is illustrated in Fig. 1. There are no linear trends but the short time series is to be borne in mind. There are smaller differences (by 3.7 times on average) among years than among months within years. By analysis of variance, year differences were not significant for any livestock ( $p=0.45$ to 0.69 ), but differences among months within a year were highly significant $(p<0.001)$.

There was a significant but smaller effect of location on mean THI $(p<0.001)$, moderated by a strong interaction between location and month $(p<0.001)$ for all livestock except layers $(p=0.42)$. The mean THI values for broilers were similar at Bodles and Kingston for all months and that at Montego Bay differed only in winter (December to February), being 1.0 unit lower on average (Fig. 3). This is primarily explained by the slightly lower winter maximum temperature at Montego Bay (Table 1) since the THI values for broilers were weighted mainly on maximum temperature. The trend differed for layer THI, which weighted maximum and minimum temperatures more evenly (effectively reflecting the stronger influence of humidity). THI values for layers were highest in Kingston throughout the year, statistically more $(1.1 \mathrm{U})$ than the other two locations in winter, but surpassing only Bodles in summer (Fig. 3).

The THI values for ruminants incorporated RH but were weighted heavily by maximum temperature. Values were highest at Bodles throughout year, with average differences of 1.6 and $2.7 \mathrm{U}$ in winter compared to Kingston and Montego Bay respectively (Fig. 3). The THI increased by a larger amount at Montego Bay than Kingston with the onset of summer, such that at Bodles, it was only $1.3 \mathrm{U}$ greater on average in summer. In all cases, significantly lower THI values were observed in winter months than summer months, differences ranging from $2.1 \mathrm{U}$ for pigs to $3.8 \mathrm{U}$ for ruminants (Table 2).

\section{Future projections}

THI derived with data from the four ensemble members of the PRECIS QUMP experiments over the period 1960 to 2099 show an overall linear increase for each livestock (Fig. 4). In Fig. 4 and for the presentation of future trends, data from the grid box over Bodles are used, as the results for the other grid boxes depicted identical trends and similar magnitudes. There was little variation among the ensemble members, and the general upward trend was well represented by the ensemble mean.

For each livestock and for each ensemble member, the mean THI was calculated for the 21-year period centred on the year each global warming target is achieved. THI values were then averaged to give the multi-model ensemble results 

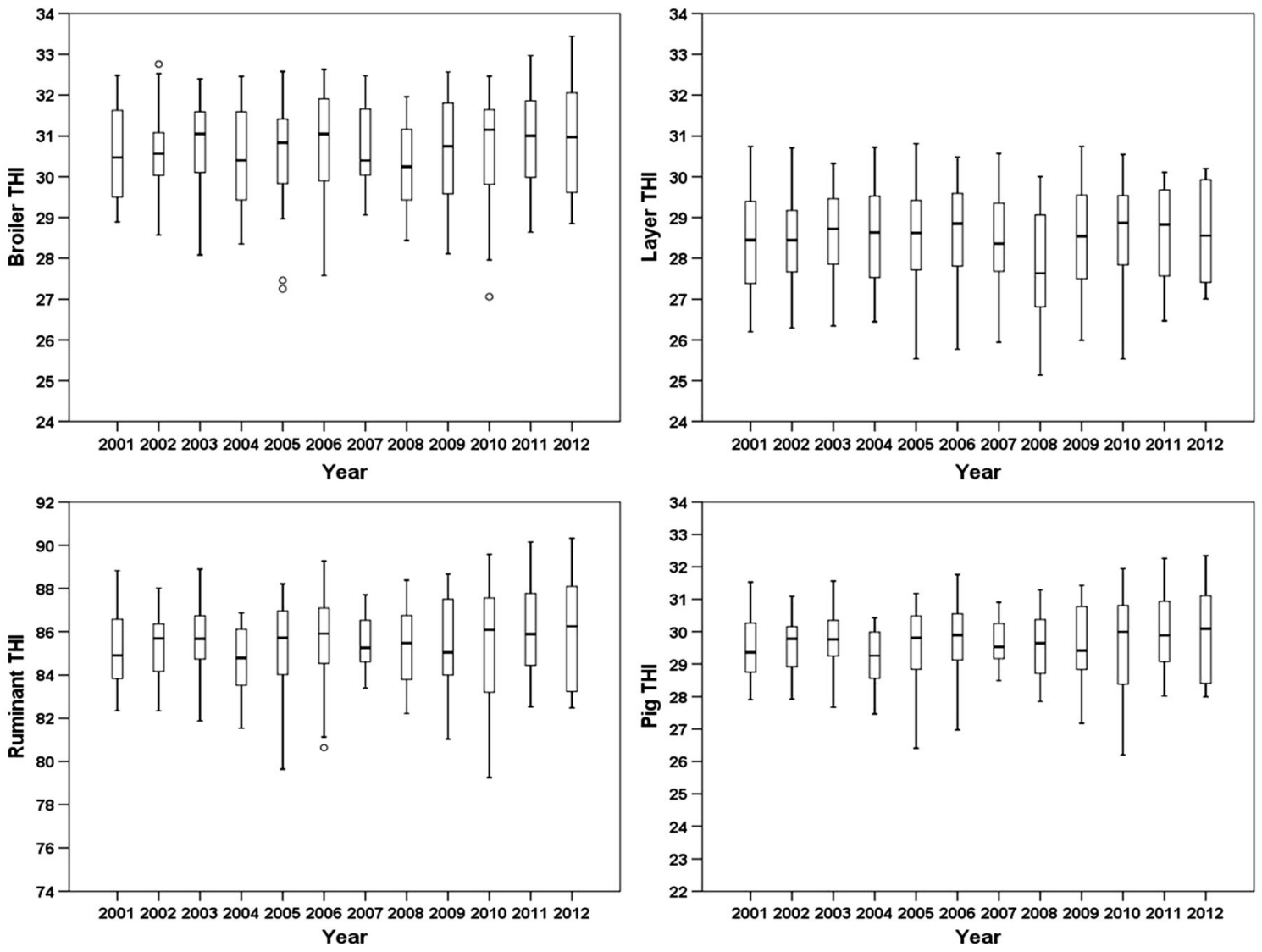

Fig. 1 Median and range of monthly temperature humidity index (THI) values for broiler chickens, layer chickens, ruminants and pigs, for 20012012 in Jamaica (based on observed temperature and relative humidity,

for each global warming target. Table 3 and Fig. 5 depict the annual increase in THI units over the baseline period (19611990) for the global warming targets of $1.5,2.0$ and $2.5^{\circ} \mathrm{C}$. At $1.5^{\circ} \mathrm{C}$, mean annual THI increase over the baseline period is $1.4 \mathrm{U}$ for chickens, 1.9 for ruminants and 1.0 for pigs (Table 3; Fig. 5).

The increased future threat is highlighted in Fig. 6 which shows future THI scenarios for each global warming target. To construct Fig. 6, the projected monthly mean increases over the model baseline were added to the present day mean monthly THI values previously depicted in Fig. 2 (also replotted as a blue line for comparison). The figure also shows horizontal lines for the highest stress threshold

category for ruminants $(\mathrm{THI} \geq 84)$ and pigs and chickens (THI $\geq 30$ ).

\section{Discussion and recommendations}

\section{Use of temperature humidity index formulations}

The THI formulations chosen for this study proved useful in characterizing past and future heat stress on livestock and poultry in Jamaica. These formulations have been widely used in research for temperate and tropical regions, e.g. for broilers and layers by Purswell et al. (2012), Behura et al. (2016) and

Table 2 Observed temperature humidity index (THI) for 'winter' (December to February) and 'summer' (July to September) in Jamaica for four types of livestock for the period 2001-2012 (mean with standard deviation of 3 months, based on averages for three sites)

\begin{tabular}{lllc}
\hline Livestock & $\begin{array}{l}\text { Winter THI: December-February } \\
\text { mean (sd) }\end{array}$ & $\begin{array}{l}\text { Summer THI: July-September } \\
\text { mean (sd) }\end{array}$ & $\begin{array}{l}\text { Difference in } \\
\text { THI units }\end{array}$ \\
\hline Broiler chicken & $29.4(0.25)$ & $31.9(0.15)$ & 2.5 \\
Layer chicken & $27.1(0.29)$ & $29.7(0.13)$ & 2.6 \\
Pig & $28.6(0.23)$ & $30.8(0.13)$ & 2.1 \\
Ruminant & $83.7(0.41)$ & $87.5(0.23)$ & 3.8 \\
\hline
\end{tabular}


Table 3 Mean annual temperature humidity index (THI) increase over baseline period (1961-1990) for global temperature increases of 1.5, 2.0 and $2.5^{\circ} \mathrm{C}$ using four-member ensemble of the Providing REgional
Climates for Impact Studies, Quantifying Uncertainty in Model Predictions experiments, for broilers, layers, ruminants and pigs in Jamaica; unit increase (range for individual ensemble members)

\begin{tabular}{llll}
\hline Livestock & \multicolumn{2}{l}{ THI unit increase over baseline (1961-1990) for temperature rises } \\
\cline { 2 - 4 } & $1.5^{\circ} \mathrm{C}$ & $2.0^{\circ} \mathrm{C}$ & $2.5^{\circ} \mathrm{C}$ \\
\hline Broiler chicken & $1.40(1.13-1.82)$ & $2.05(1.80-2.56)$ & $2.52(2.30-2.93)$ \\
Layer chicken & $1.43(1.17-1.79)$ & $2.07(1.80-2.54)$ & $2.52(2.32-2.89)$ \\
Ruminant & $1.89(1.50-2.40)$ & $2.71(2.33-3.34)$ & $3.27(2.99-3.75)$ \\
Pig & $1.05(0.83-1.33)$ & $1.50(1.29-1.85)$ & $1.81(1.65-2.07)$ \\
\hline
\end{tabular}

Aluwong et al. (2017), for pigs by Fitzgerald et al. (2009) and Abi Saab et al. (2011) and for ruminants by Ravagnolo et al. (2000), Hahn et al. (2003), Hernández et al. (2011) and Schönhart and Nadeem (2015). Bohmanova et al. (2007) noted that the ruminant formulation was designed for cattle raised outdoors. Being based on maximum daily temperature, the calculated THI values reflect exposure to the maximum levels of heat recorded.

The effect on poultry THI values of use of $T_{\min }$ with $T_{\max }$ in lieu of $T_{\mathrm{wb}}$ with $T_{\mathrm{db}}$ was small, and since differences were consistent, the trends observed in the results are accepted as valid. While the small underestimation implies that current and future heat stress could be slightly greater, any actual difference is likely insignificant, especially considering the levels projected for temperature increase.

The THI categories of heat stress used in this study were adopted as guides. It is noted that defining ranges for categories of heat stress can be somewhat arbitrary, as heat stress depends not only on the prevailing climate and THI formulation but also on the practices employed to manage heat stress which determine micro-climate (Dikmen and Hansen 2009),

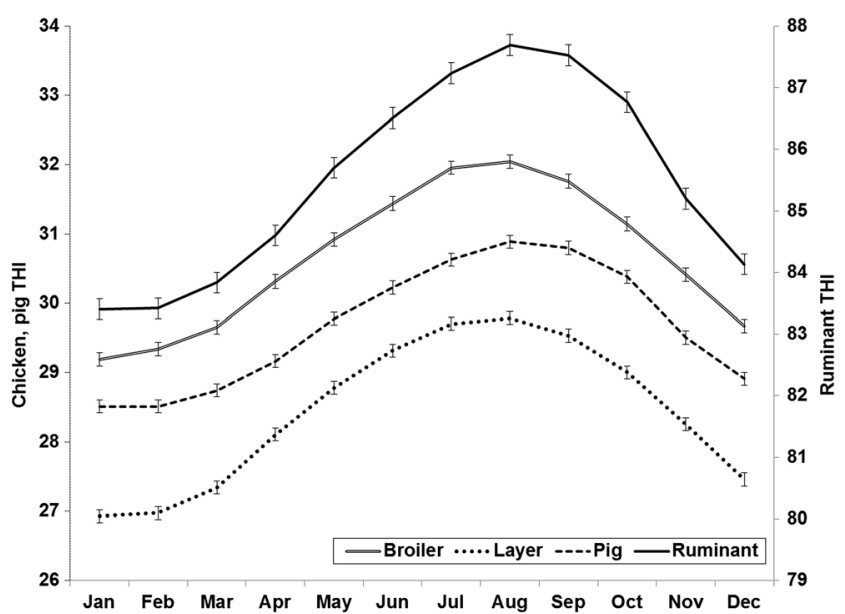

Fig. 2 Observed mean monthly temperature humidity index (THI) for broiler chickens, layer chickens, pigs and ruminants for the period 2001-2012; mean values from three locations in Jamaica ( \pm standard error per livestock) as well as the breed of the animal, how well adapted it is to the climate and its physiological state (Tao and Xin 2003; Dikmen and Hansen 2009; Ajakaiye et al. 2011).

\section{Historical analysis}

Monthly variations showed similar trends for the four types of livestock/poultry (Fig. 2), with plots generally tracking the typical temperature profile for Jamaica and reflecting the impact of season. Using the heat stress levels previously described for ruminants (NOAA 1976) and pigs and poultry (Marai et al. 2001), the THI values determined for Jamaica indicate that animals in ambient field conditions experience considerable periods of heat stress all year (Fig. 2; Table 2). THI values fell in one of the categories of thermal stress even in the cooler winter months. Values in Table 2 are consistent with the high values reported for tropical and subtropical regions (Ingraham et al. 1974; Du Preez et al. 1990; Abu-Dieyeh 2006; Hernández et al. 2011; Ayo et al. 2014) and reflect the almost constant heat challenge in these regions, as discussed by Renaudeau et al. (2012). During an experiment in Cuba on dietary supplementation for layers, Ajakaiye et al. (2011) determined the THI range to fall in categories of severe heat stress. Data from Hernández et al. (2011) in Veracruz, Mexico, using maximum monthly temperatures, also produced high THI values for ruminants with a similar seasonal effect: winter THI of 75-76 increasing to 85-86 in summer, for the period 1991-2008. The lower winter THI than in Jamaica reflects Mexico's higher latitudinal position.

The significant, but small, effect of location varied with season. Although the winter THI values for ruminants at Montego Bay were lower than at Kingston by $1.2 \mathrm{U}$ on average, they were statistically equivalent in summer. These results reflect the influence of high maximum temperatures and also introduce the role of humidity. Rainfall and RH were highest at Montego Bay (Table 1) resulting in the ruminant THI increasing more steeply than at the other two locations after the end of the cooler winter period. A similar trend occurred for the THI values for pigs, which have an equivalent weighting of temperature and $\mathrm{RH}$, but differences in THI units were smaller (Fig. 3). 
Fig. 3 Observed mean monthly temperature humidity index (THI) at three locations in Jamaica: Kingston, Montego Bay and Bodles, for 2001-2012 for broiler chickens, layer chickens, ruminants and pigs $( \pm$ standard error for years per livestock)
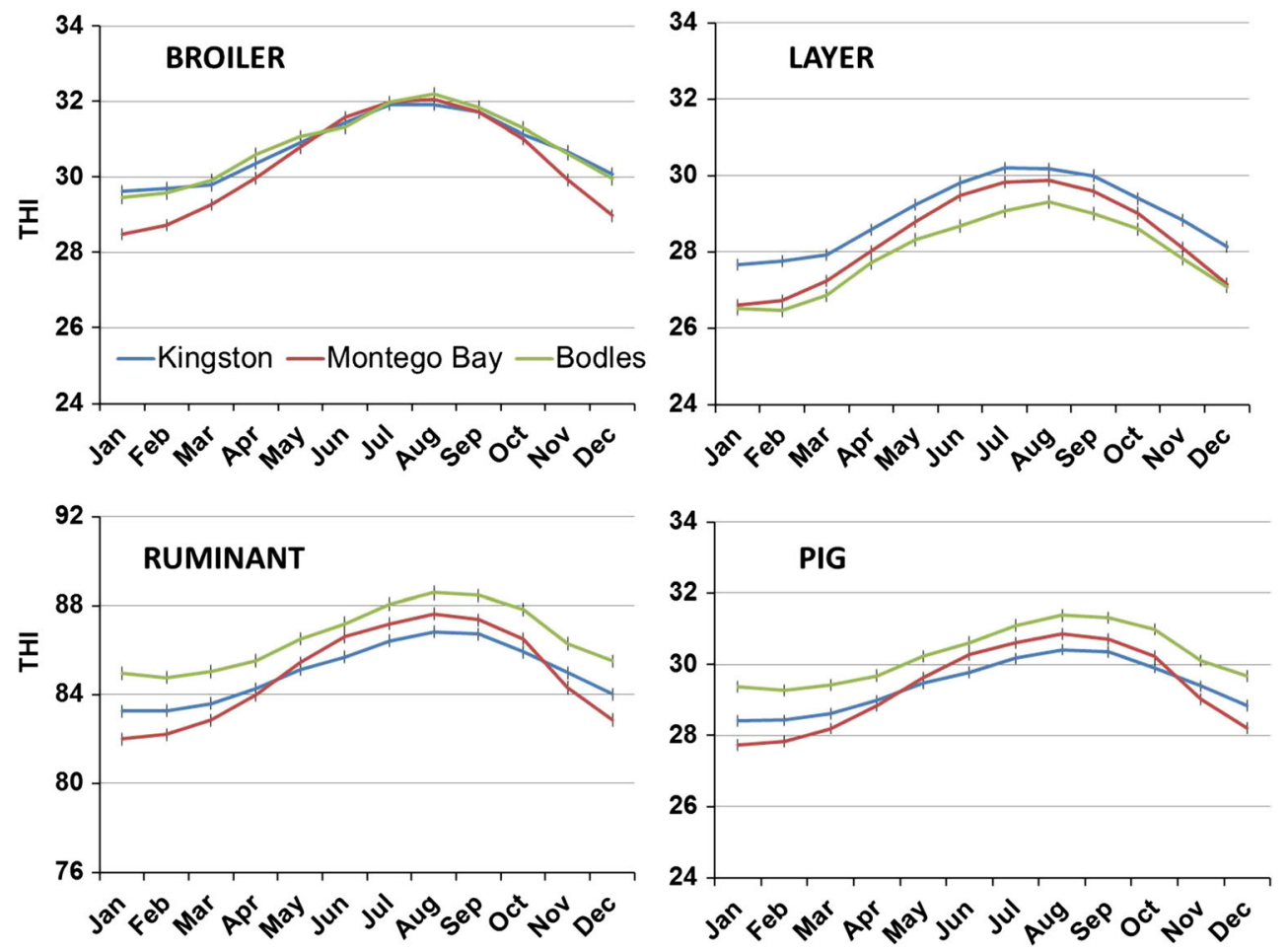

The sites selected are all at low elevation which may experience higher heat stress than farms located at higher elevation. However, the majority of livestock farms are at low altitude, so that the levels of stress reported are representative of those experienced by animals in Jamaica. In general, the sites are expected to represent conditions within their agro-ecological zone, while recognizing that variation within zones will occur due to other geophysical characteristics in addition to altitude. The sites fall within two (coastal and interior) of the four rainfall zones identified for Jamaica by CSGM (2017), which also coincide with most of the agricultural production areas.

The differences across the three sites suggest that heat stress mitigation actions will vary according to location. Jini et al. (2015) examined variations in temperature and $\mathrm{RH}$ in different climatological areas in NE India and highlighted the need for poultry farmers and extension personnel to know the critical periods of the year when management of heat stress becomes essential for their locations. This was also noted by Du Preez et al. (1990) in South Africa and de la Casa and Ravelo (2003) in Argentina for dairy cattle and Somparn et al. (2004) in Thailand for cattle and buffalo.

It is important to note that the THI values in this study were calculated using maximum daily values and the influence of diurnal variation on heat stress was not considered. Factors such as period of day, duration of heat stress, accumulated heat stress (known as THI hours), correlation with animal behaviour, and extent of recovery periods also play important roles in the heat stress actually experienced by livestock
(Kadzere et al. 2002; de la Casa and Ravelo 2003; Hahn et al. 2009; Ajakaiye et al. 2011; Hernández et al. 2011).

\section{Future projections}

The common trend across all livestock suggests that, notwithstanding the climatic parameters used and how they are weighted in the THI calculations, the future Caribbean climate is expected to produce steadily increasing heat stress for animals (Figs. 4 and 5), which would threaten livestock productivity. Since it can be assumed that each model produced a consistent bias (exhibits stationarity), differences in the future compared to the baseline were useful in illustrating projected changes over current THI values (Fig. 6). For broilers and ruminants, at $1.5^{\circ} \mathrm{C}$, every month can be categorized as very severe, in comparison to the present-day where winter months fall below this threshold. For layers (pigs), 7 (9) months of the year are projected to fall in the two highest stress categories for the $1.5^{\circ} \mathrm{C}$ global warming target, compared to 0 (5) months in the present-day. The threats further intensify for successively higher global warming targets. At $2.0^{\circ} \mathrm{C}$, all months (broilers and ruminants) or most months (layers and pigs) represent very severe conditions. At $2.5^{\circ} \mathrm{C}$, except for layers, all months fall into the categories of very severe (Fig. 6).

The projected increases in THI through to the end of the century (Fig. 4) strongly mirror the linear increases in temperature projected for the Caribbean (see Fig. 3 of Taylor et al. 2018) and Jamaica (CSGM 2012, 2017). This is not to suggest that other meteorological factors do not influence the THI; for 
Fig. 4 Temperature humidity index (THI) for Jamaica derived from four ensemble members of the Providing REgional Climates for Impact Studies, Quantifying Uncertainty in Model Predictions experiments from 1960 to 2099 for broiler chickens, layer chickens, ruminants and pigs. Bold line represents the ensemble mean, and each of the four ensemble members is represented by lighter lines
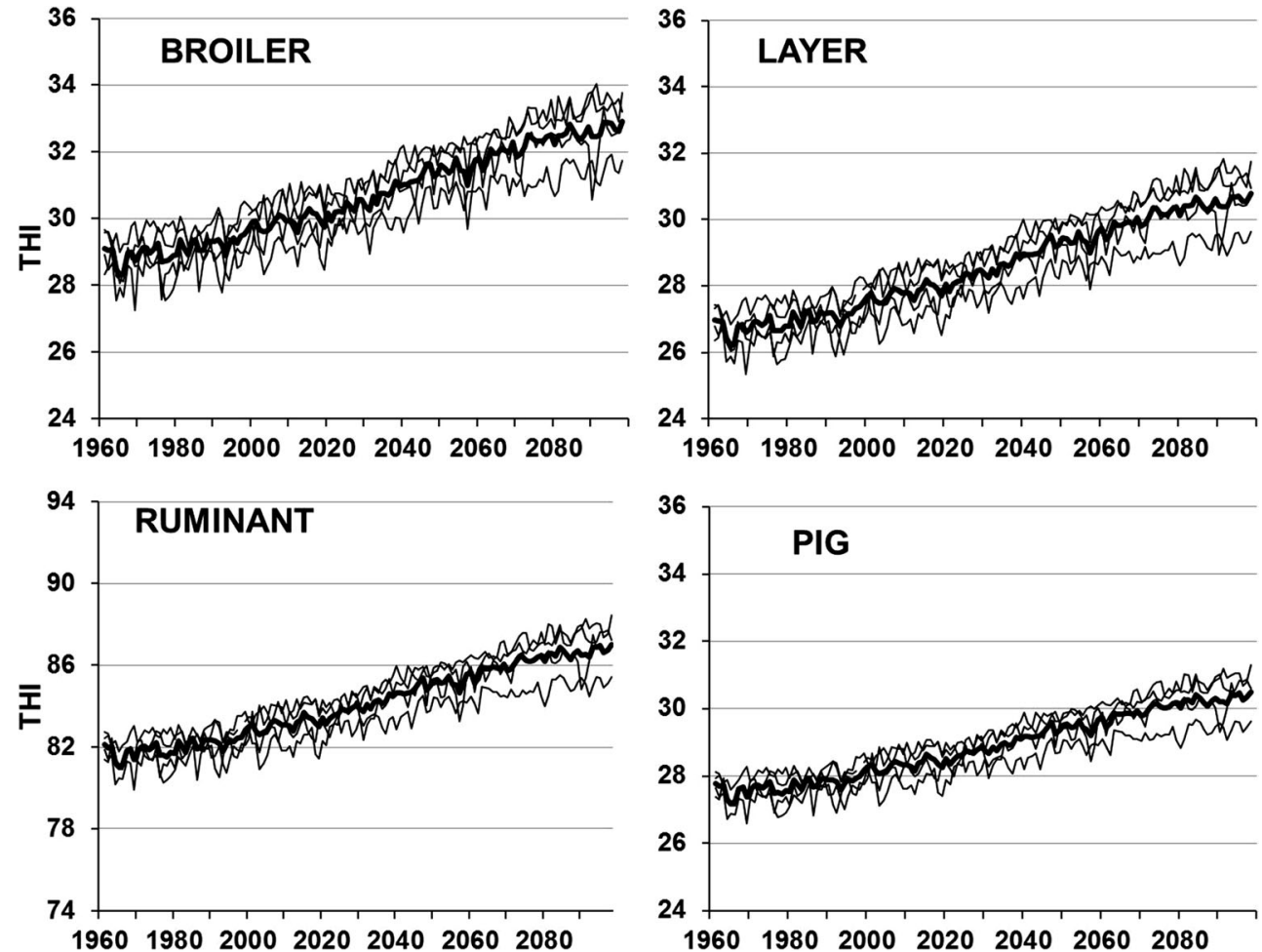

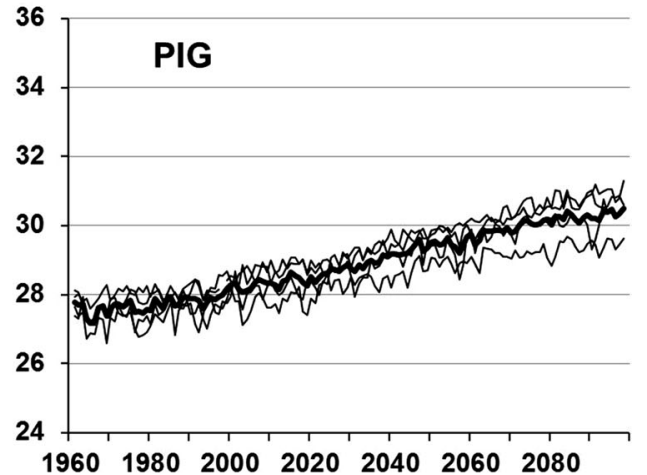

example, if $\mathrm{RH}$ is projected to be lower, this would moderate expected THI increases. Lower rainfall also negatively impacts pasture production, a major component of ruminant feed in Jamaica (Hughes et al. 2011). Taylor et al. (2018), however, show that for Jamaica, future changes in annual rainfall are relatively small for the global warming targets examined (though seasonal changes may be larger), with an increase of $5 \%$ at $1.5{ }^{\circ} \mathrm{C}$ (statistically significant) but a decrease by 2 and $3 \%$ respectively for 2.0 and $2.5^{\circ} \mathrm{C}$ (not significant). Furthermore,

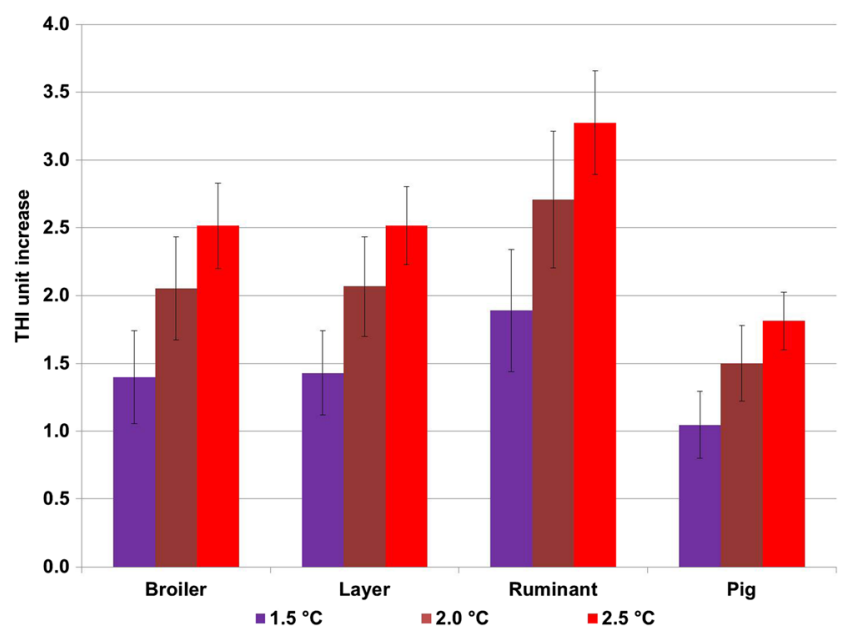

Fig. 5 Mean annual temperature humidity index (THI) unit increase from multi-model ensemble at change periods compared to baseline period of 1961-1990, for broilers, layers, ruminants and pigs in Jamaica (error bar represents range of the four models comprising the multi-model ensemble) the previous section already noted the importance of maximum temperature for the different agro-ecological locations, so that relatively small reductions in $\mathrm{RH}$ would not mitigate the effect of significant intensification of temperature.

Finally, it is noted that the mean year of occurrence of $1.5^{\circ} \mathrm{C}$ is 2027 (range of 2019 to 2043 across ensemble members). A number of other studies also suggest similar attainment dates in the 2020 s for $1.5{ }^{\circ} \mathrm{C}$ (Taylor et al. 2018; Karmalkar and Bradley 2017). Therefore, although the highest change in THI is noted with a global mean surface temperature increase of $2.5^{\circ} \mathrm{C}$ which occurs later in the century, potentially damaging heat stress is anticipated long before this and within the next decade. The mean attainment years of 2.0 and $2.5^{\circ} \mathrm{C}$ are 2044 (range of 2035 to 2069) and 2057 (range of 2044 to 2087) respectively for the QUMP simulations using the A1B scenario.

\section{Recommendations}

The results of this study suggest the need for the implementation or scaling up of management options in the face of higher levels of heat stress even if global mean surface temperatures are limited to $1.5^{\circ} \mathrm{C}$ above pre-industrial levels by the end of the century. For the Caribbean, these should include the following:

- The development of early warning systems for detection of heat stress in regional livestock and to trigger appropriate management responses 
Fig. 6 Future mean monthly temperature humidity index (THI) for global warming targets of 1.5 , 2.0 and $2.5^{\circ} \mathrm{C}$. Future temperature humidity index scenarios determined by adding the multimodel ensemble change for each month with respect to the model baseline to present-day (20012012) monthly mean values (blue line). Plots shown for broilers, layers, ruminants and pigs in Jamaica. Horizontal line indicates threshold for emergency for ruminants $(\geq 84)$ and chickens and pigs ( $\geq 30$ ) (error bar represents range of the four ensemble members)
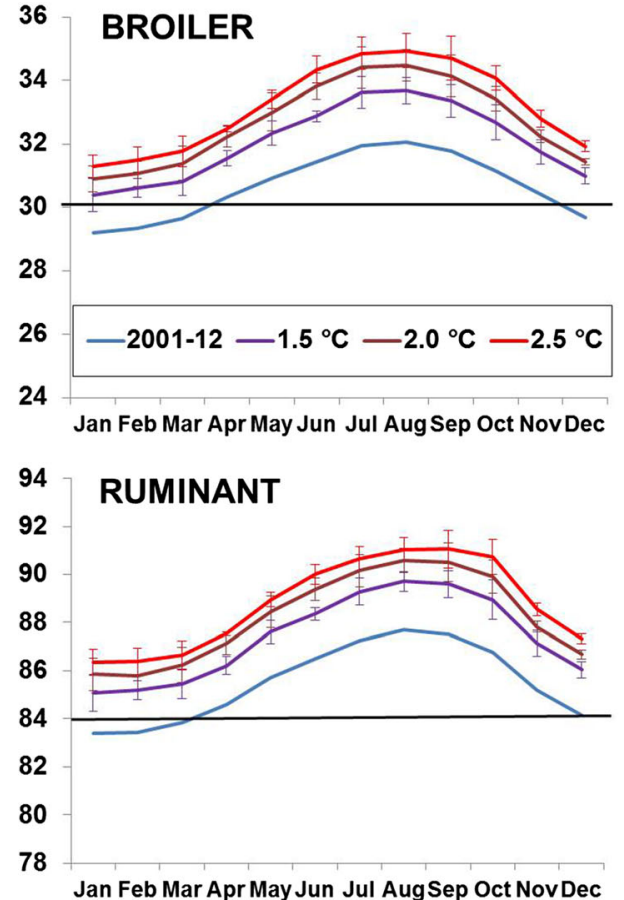

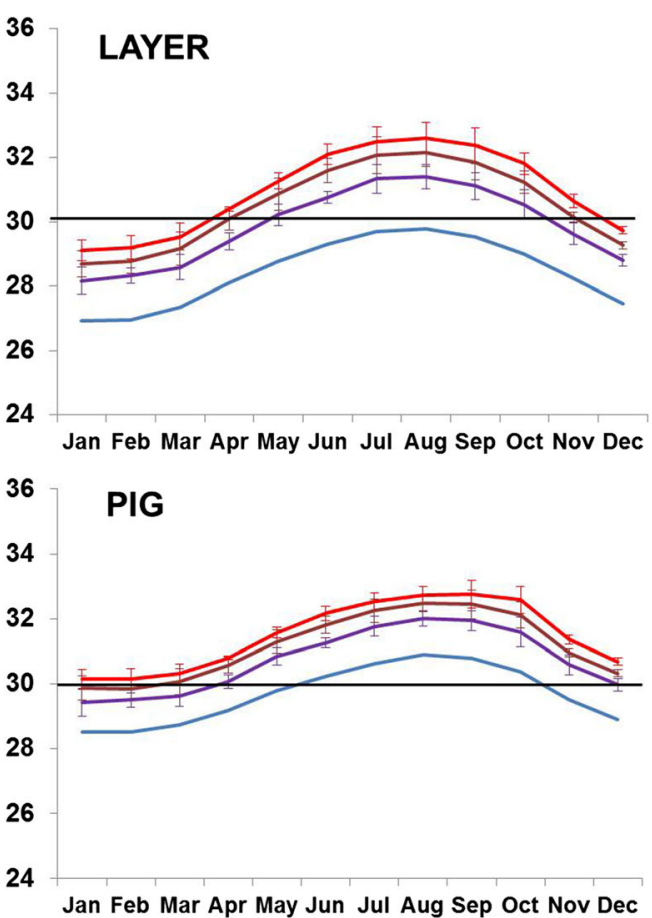

- The training and sensitization of livestock farmers and extension officers in Jamaica and the region to better understand heat stress mitigation, including how to interpret indices like the THI and how best to prioritize actions that enhance adaptive capacity based on them

Specifically, for the livestock examined in this study, the following management strategies are suggested.

- For broilers, apart from cooling mechanisms, interventions could include improved litter management to prevent ammonia build-up; lowering the stocking density in houses; marketing of birds at an earlier stage; nutritional interventions, e.g. the use of vitamins, electrolyte and mineral supplementation including chromium and zinc (Lin et al. 2006); and exploring more climate resilient strains (Cahaner and Leenstra 1992; Lin et al. 2006).

- Strategies for pigs would be similar to poultry, including environment modification and nutritional interventions contingent on available budget. Other options might depend on farm size, e.g. large farmers focusing future production in ventilated tunnel housing versus smaller farmers installing fans with misting or sprinkler capability in open-sided, naturally ventilated houses and reducing stocking densities. To reduce energy use, passive cooling systems are encouraged.

- Shade for beef, dairy cattle, sheep and goat at pasture is an important strategy towards mitigating heat stress (Lopes et al. 2016). Other options include night grazing with adequate lighting and security; nutritional management, such as dietary supplementation; and breeding research to assess for heat tolerance as well as milk production (Galukande et al. 2013).

\section{Conclusion}

This study examined thermal heat stress conditions for livestock of importance to the agricultural sector in Jamaica and typical for the Caribbean region. THI is used to deduce historical monthly and seasonal patterns of heat stress for broilers, layers, ruminants and pigs for three different agroecological locations. THI has been little studied for Jamaica and the wider Caribbean, and as such, this study provides baseline values for future exploration. The study also provides projections of potential future heat stress as suggested from THI values using data from a regional climate model.

From the results presented, the following are noted.

1. Notwithstanding the relatively small annual range of Caribbean surface temperatures, monthly/seasonal THI variability appears to be more important than interannual variability for present-day conditions. However, the short time series (12 years) is to be borne in mind. The effect of location is also significant, notwithstanding a smaller impact on the heat stress experienced by livestock in Jamaica.

2. There is evidence that animals in ambient field conditions in Jamaica (and by extrapolation much of the Caribbean region) already experience considerable periods of heat 
stress even during relatively cooler northern hemisphere winter months.

3. Future THI values will exceed current values. Even at a global mean surface temperature rise of $1.5^{\circ} \mathrm{C}$ above preindustrial levels, there are marked increases in THI for all livestock examined. Given that regional livestock are already stressed, $1.5^{\circ} \mathrm{C}$ may represent a significant global warming threshold, above which persistent heat stress will likely be experienced.

4. A global mean surface temperature increase of $2.0^{\circ} \mathrm{C}$ or higher versus $1.5^{\circ} \mathrm{C}$ will result in further increases in THI and the highest levels of heat stress year round. These levels will likely exceed the limits beyond which normal thermoregulation by livestock in the Caribbean can be accomplished without energy-intensive heat mitigation systems.

5. The current work provides some justification for the call by Small Island Developing States to keep global temperatures to no more than $1.5^{\circ} \mathrm{C}$ above pre-industrial levels given the likely impact to livestock of not doing so. In the absence of mitigation, the negative consequences on animal physiology and consequently production will be felt sooner than later and greatly exacerbated in the long term.

Finally, it is noted that in a warmer future world, there will be increasing need for cooling systems, especially passive technologies in light of increasing costs of water and electricity. There also should be a regional push to have mechanized systems powered by renewable energy sources to offset potential increases in greenhouse gas emissions that would otherwise result from the use of fossil fuels.

Acknowledgements This study is a part of the Caribbean 1.5 project that attempts to investigate the implications of global warming of 1.5, 2.0 and $2.5^{\circ} \mathrm{C}$ above pre-industrial levels. Model data for the research was provided by the Climate Studies Group Mona and historical data by the Meteorological Service, Jamaica.

Funding information The work is funded by the Caribbean Development Bank and the Investment Plan for the Caribbean Track of the Pilot Program for Climate Resilience.

Open Access This article is distributed under the terms of the Creative Commons Attribution 4.0 International License (http:// creativecommons.org/licenses/by/4.0/), which permits unrestricted use, distribution, and reproduction in any medium, provided you give appropriate credit to the original author(s) and the source, provide a link to the Creative Commons license, and indicate if changes were made.

\section{References}

Abi Saab S, Sleiman FT, Kallassy N, Darweesh WY, Aad PY (2011) Effect of adaptation and heat stress on reproductive performances of Fattail Awassi rams in Eastern Mediterranean. Lebanese Sci J 12: $31-44$
Abu-Dieyeh ZHM (2006) Effect of chronic heat stress and long-term feed restriction on broiler performance. Int J Poult Sci 5:185-190. https://doi.org/10.3923/ijps.2006.185.190

Ajakaiye JJ, Perez-Bello A, Mollineda-Trujillo A (2011) Impact of heat stress on egg quality in layer hens supplemented with 1-ascorbic acid and dl-tocopherol acetate. Vet Arhiv 81:119-132 http://vetarhiv.vef. unizg.hr/papers/2011-81-1-12.pdf

Aluwong T, Sumanu VO, Ayo JO, Ocheja BO, Zakari FO, Minka NS (2017) Daily rhythms of cloacal temperature in broiler chickens of different age groups administered with zinc gluconate and probiotic during the hot-dry season. Physiol Rep 5(12): e13314. https://doi.org/10.14814/phy2.13314

Amundson JL, Mader TL, Rasby RJ, Hu QS (2006) Environmental effects on pregnancy rate in beef cattle. J Anim Sci 84: 3415-3420. https://doi.org/10.2527/jas.2005-611

Armstrong DV (1994) Heat stress interaction with shade and cooling. J Dairy Sci 77:2044-2050. https://doi.org/10.3168/jds.S00220302(94)77149-6

Ayo JO, Danbirini S, Egbuniwe IC, Sinkalu VO (2014) Cloacal temperature responses and some performance indices in Black Harco pullets administered with betamint during the hot-dry season. J Veterinar Sci Technol 5(2):1-8. https://doi.org/10.4172/2157-7579. 1000166

Behura NC, Kumar F, Samal L, Sethy K, Behera K, Nayak GD (2016) Use of temperature-humidity index (THI) in energy modeling for broiler breeder pullets in hot and humid climatic conditions. J. Livestock Sci 7:75-83

Ben Salem M, Bouraoui R (2009) Heat stress in Tunisia: effects on dairy cows and potential means of alleviating it. South African J Anim Sci 39:256-259. https://doi.org/10.4314/sajas.v40i5.65351

Benjamin L, Thomas A (2016) $1.5^{\circ} \mathrm{C}$ to stay alive? AOSIS and the long term temperature goal in the Paris Agreement. IUCN Acad Environ Law e-Journal 7:122-129 http://www.iucnael.org/en/e-journal

Bohmanova J, Misztal I, Cole JB (2007) Temperature-humidity indices as indicators of milk production losses due to heat stress. J Dairy Sci 90:1947-1956. https://doi.org/10.3168/jds.2006-513

Buffington DE, Collazo-Arocho A, Canton GH, Pitt D, Thatcher WW, Collier RJ (1981) Black globe-humidity index (BGHI) as comfort equation for dairy cows. Trans ASAE 24:711-714. https://doi.org/ $10.13031 / 2013.34325$

Cahaner A, Leenstra F (1992) Effect of high temperature on growth and efficiency of male and female broilers from lines selected for high weight gain, favourable feed conversion, and high or low fat content. Poult Sci 71:1237-1250. https://doi.org/10.3382/ps.0711237

Campbell JD, Taylor MA, Stephenson TS, Watson RA, Whyte FS (2011) Future climate of the Caribbean from a regional climate model. Int J Climatol 31:1866-1878. https://doi.org/10.1002/joc.2200

Caribbean Agricultural Research and Development Institute (CARDI) (2013) The small ruminant industry in CARICOM countries with particular reference to Jamaica and Trinidad \& Tobago. CARDI TT/ 001/14. http://www.cardi.org/wp-content/uploads/downloads/2014/ 02/The-SR-Industry-in-CARICOM-with-particular-reference-toTrinidad-and-Tobago.pdf

Climate Studies Group, Mona (CSGM) (2012) State of the Jamaican climate 2012: information for resilience building (full report). Planning Institute of Jamaica (PIOJ). Kingston, Jamaica

Climate Studies Group, Mona (CSGM) (2017) State of the Jamaican climate 2015: information for resilience building (full report). Planning Institute of Jamaica (PIOJ), Kingston

Daghir NJ (2008) Broiler feeding and management in hot climates. In: Daghir NJ (ed) Poultry production in hot climates, 2nd edn. CABI, UK, pp 220-267

de la Casa AC, Ravelo AC (2003) Assessing temperature and humidity conditions for dairy cattle in Córdoba, Argentina. Int J Biometeorol 48:6-9. https://doi.org/10.1007/s00484-003-0179-x 
DeShazer JA, Hahn GL, Xin H (2009) Chapter 1: basic principles of the thermal environment and livestock energetics. In: DeShazer JA (ed) Livestock energetics and thermal environmental management. ASABE, MI, USA, pp 1-22

Dikmen S, Hansen PJ (2009) Is the temperature-humidity index the best indicator of heat stress in lactating dairy cows in a subtropical environment? J Dairy Sci 92:109-116. https://doi. org $/ 10.3168 /$ jds.2008-1370

Du Preez JH, Hattingh PJ, Giesecke WH, Eisenberg BE (1990) Heat stress in dairy cattle and other livestock under Southern African conditions. III. Monthly temperaturehumidity index mean values and their significance in the performance of dairy cattle. Onderstepoort J Vet Res 57: 243-248

Eirich RL, Griffin D, Brown-Brandl TM, Eigenberg RA, Mader TL, Mayer JJ (2015) Feedlot heat stress information and management guide. University of Nebraska-Lincoln Extension Pubn. G2266. http://extensionpublications.unl.edu/assets/html/g2266/build/ g2266.htm Accessed 21 July 2017

Fitzgerald RF, Stalder KJ, Matthews JO, Schultz Kaster CM, Johnson AK (2009) Factors associated with fatigued, injured, and dead pig frequency during transport and lairage at a commercial abattoir. J Anim Sci 87:1156-1166. https://doi.org/10.2527/jas.2008-1270

Food and Agriculture Organization of the United Nations (FAO) (2015). State of food security in the CARICOM Caribbean. Meeting the 2015 hunger targets: taking stock of uneven progress. Subregional Office for the Caribbean, FAO. Bridgetown. http://www.fao.org/3/ai5131e.pdf. Accessed 10 Apr 2018

Frank KL, Mader TL, Harrington JA, Hahn GL (2001) Potential climate change effects on warm-season livestock productions in the Great Plains. Journal series no. 14462, Agric. Res. Div., University of Nebraska, USA

Galukande E, Mulindwa H, Wurzinger M, Roschinsky R, Mwai AO, Sölkner J (2013) Cross-breeding cattle for milk production in the tropics: achievements, challenges and opportunities. Anim Genet Resour 52:111-125. https://doi.org/10.1017/S2078633612000471

Gantner V, Mijić P, Jovanovac S, Raguž N, Bobić T, Kuterovac K (2012) Influence of temperature-humidity index (THI) on daily production of dairy cows in Mediterranean region in Croatia. In: Casasús I, Rogošiç J, Rosati A, Štokoviç I, Gabiña D (ed) Animal farming and environmental interactions in the Mediterranean region. European Federation of Animal Sciences (EAAP) scientific series no. 131, Wageningen Academic Publishers, pp 71-78

Hahn GL, Mader TL, Eigenberg RA (2003) Perspective on development of thermal indices for animal studies and management. In: Lacetera $\mathrm{N}$, Bernabucci U, Khalifa HH, Ronchi B, Nardone A (eds) Interaction between climate and animal production. EAAP technical series 7. Wageningen Academic Publishers, The Netherlands, pp $31-44$

Hahn GL, Gaughan JB, Mader TL, Eigenberg RA (2009) Chapter 5: thermal indices and their applications for livestock environments. In: DeShazer JA (ed) Livestock energetics and thermal environmental management. ASABE, MI, USA, pp 113-130. https://doi.org/10. $13031 / 2013.28298$

Hernández A, Domínguez B, Cervantes P, Muñoz-Melgarejo S, SalazarLizán S, Tejeda-Martínez A (2011) Temperature-humidity index (THI) 1917-2008 and future scenarios of livestock comfort in Veracruz, México. Atmósfera 24:89-102

Holik V (2009) Management of laying hens to minimize heat stress. Lohmann Information 44:16-29

Hughes MP, Jennings PGA, Mlambo V, Lallo CHO (2011) Exploring seasonal variations in sward characteristics and nutritive value of tropical pastures grazed by beef and dairy cattle on commercial farms in Jamaica. J Anim Sci Adv 1:47-60
Ingraham RH, Gillette DD, Wagner WD (1974) Relationship of temperature and humidity to conception rate of Holstein cows in subtropical climate. J Dairy Sci 57:476-481. https://doi.org/10.3168/jds. S0022-0302(74)84917-9

Intergovernmental Panel on Climate Change (IPCC) (2000). Emissions scenarios, a special report of Working Group III of the Intergovernmental Panel on Climate Change. Cambridge University Press, Cambridge, UK. http://www.ipcc.ch/ipccreports/ sres/emission/index.php?idp $=0$

Jennings PGA (2006) Livestock production in unfavourable economic environments: strategies for attaining sustained competitive advantage. BookSurge Publishing, Charleston

Jini D, Bhagawati K, Bhagawati R, Rajkhowa DJ (2015) Identification of critical periods environmentally sensitive to normal performance of Vanaraja poultry breed in climatically different locations. Int Lett Nat Sci 46:76-83. https://doi.org/10.18052/www.scipress.com/ ILNS.46.76

Jones RG, Noguer M, Hassell D, Hudson D, Wilson S, Jenkins G, Mitchell J (2003) Generating high resolution climate change scenarios using PRECIS. UNDP, New York

Jones RG, Noguer M, Hassell D, Hudson D, Wilson S, Jenkins G, Mitchell J (2004) Generating high resolution climate change scenarios using PRECIS. Met Office Hadley Centre, Exeter

Jones PD, Harpham C, Harris I, Goodess CM, Burton A, Centella-Artola A, Taylor MA, Benzanilla-Marlot A, Campbell JD, Stephenson TS, Joslyn O, Nicholls K, Baur T (2015) Long-term trends in precipitation and temperature across the Caribbean. Int J Climatol 36:3314 3333. https://doi.org/10.1002/joc. 4557

Kadzere CT, Murphy MR, Silanokove N, Maltz E (2002) Heat stress in lactating dairy cows: a review. Livest Prod Sci 77:59-91. https://doi. org/10.1016/S0301-6226(01)00330-X

Karmalkar AV, Bradley RS (2017) Consequences of global warming of $1.5^{\circ} \mathrm{C}$ and $2{ }^{\circ} \mathrm{C}$ for regional temperature and precipitation changes in the contiguous United States. PLoS One 12(1):e0168697. https://doi.org/10.1371/journal.pone.0168697

Karmalkar AV, Taylor MA, Campbell J, Stephenson T, New M, Centella A, Benzanilla A, Charlery J (2013) A review of observed and projected changes in climate for the islands in the Caribbean. Atmosfera 26:283-309. https://doi.org/10.1016/S0187-6236(13) 71076-2

Lallo CH, Paul I, Bourne G (2012) Thermoregulation and performance of British Anglo-Nubian and Saanen goats reared in an intensive system in Trinidad. Trop Anim Health Prod 44:491-496. https://doi. org/10.1007/s11250-011-9924-z

Lallo CHO, Smalling S, Facey A, Hughes M (2017) The impact of climate change on small ruminant performance in Caribbean communities. In: Ganpat W, Isaac W (eds) Environmental sustainability and climate change adaptation strategies. IGI Global, pp 296-321

Lin H, Jiao HC, Buyse J, Decuypere E (2006) Strategies for preventing heat stress in poultry. World's Poultry Science Journal 26:71-85. https://doi.org/10.1079/WPS200585

Lopes LB, Eckstein C, Pina DS, Carnevalli RA (2016) The influence of trees on the thermal environment and behaviour of grazing heifers in Brazilian Midwest. Trop Anim Health Prod 48:755-761. https://doi. org/10.1007/s11250-016-1021-x

Lu CD (1989) Effect of heat stress on goat production. Small Rumin Res 2:151-162. https://doi.org/10.1016/0921-4488(89)90040-0

Mader TL, Davis MS, Brown-Brandl T (2006) Environmental factors influencing heat stress in feedlot cattle. J Anim Sci 84:712-719. https://doi.org/10.2527/2006.843712x

Marai IFM, Habeeb AAM (2010) Buffalo's biological function as affected by heat stress - a review. J Livestock Sci 127:89-109

Marai IFM, Ayyat MS, Abd El-Monem UM (2001) Growth performance and reproductive traits at first parity of New Zealand white female rabbits as affected by heat stress and its alleviation under Egyptian 
conditions. Trop Anim Health Prod 33:451-462. https://oi.org/10. 1023/A:1012772311177

Marai IFM, El-Darawany AA, Fadiel A, Abdel-Hafez MAM (2007) Reproductive performance traits as affected by heat stress and its alleviation in sheep a review. Trop Subtrop Agroeco 8:209-234

Mashaly MM, Hendricks GL III, Kalama MA, Gehad AE, Abbas AO, Patterson PH (2004) Effect of heat stress on production parameters and immune responses of commercial laying hens. Poult Sci 83: 889-894. https://doi.org/10.1093/ps/83.6.889

McSweeney CF, Jones RG, Booth BBB (2012) Selecting ensemble members to provide regional climate change information. J Clim 25: 7100-7121. https://doi.org/10.1175/JCLI-D-11-00526.1

Murphy JM, Booth BB, Collins M, Harris GR, Sexton DMH, Webb MJ (2007) A methodology for probabilistic predictions of regional climate change from perturbed physics ensembles. Phil Trans R Soc A 365:1993-2028. https://doi.org/10.1098/rsta.2007.2077

National Oceanic and Atmospheric Administration (NOAA) (1976) Livestock hot weather stress. Operations manual letter C-31-76, Department of Commerce, NOAA, National Weather Service Central Region, Kansas City

National Research Council (NRC) (1971) A guide to environmental research on animals. Natl. Acad. Sci., Washington, DC, USA

Nurse LA, McLean RF, Agard J, Briguglio LP, Duvat-Magnan V, Pelesikoti N, Tompkins E, Webb A (2014) Small islands. In: Barros VR, Field CB, Dokken DJ, Mastrandrea MD, Mach KJ, Bilir TE, Chatterjee M, Ebi KL, Estrada YO, Genova RC, Girma B, Kissel ES, Levy AN, MacCracken S, Mastrandrea PR, White LL (ed.) Climate change 2014: impacts, adaptation, and vulnerability. Part B: regional aspects. Contribution of Working Group II to the Fifth Assessment Report of the Intergovernmental Panel on Climate Change. Cambridge University Press, Cambridge and New York, pp. 1613-1654

Purswell JL, Dozier III WA, Olanrewaju HA, Davis JD, Xin H, Gates RS (2012) Effect of Temperature-Humidity Index on live performance in broiler chickens grown from 49 to 63 days of age. Ninth International Livestock Environment Symposium, Valencia, Spain, Paper: ILES12-0265. ASABE, St. Joseph, MI, USA

Ravagnolo O, Misztal I, Hoogenboom G (2000) Genetic component of heat stress in cattle, development of heat index function. J Dairy Sci 83:2120-2125. https://doi.org/10.3168/jds.S0022-0302(00)75094-6

Renaudeau D, Collin A, Yahav S, de Basilio V, Gourdine JL, Collier RJ (2012) Adaptation to hot climate and strategies to alleviate heat stress in livestock production. Animal 6:707-728. https://doi.org/ $10.1017 / \mathrm{S} 1751731111002448$

Salama AAK, Caja G, Hamzaoui S, Badaoui B, Castro-Costa A, Facanha DAE, Guilhermino MM, Bozzi R (2014) Different levels of response to heat stress in dairy goats. Small Rumin Res 121:7379. https://doi.org/10.1016/j.smallrumres.2013.11.021

Schönhart M, Nadeem I (2015) Direct climate change impacts on cattle indicated by THI models. Adv Anim Biosci 6:17-20. https://doi.org/ $10.1017 / \mathrm{S} 2040470014000430$

Silva d RG, Morais DAEF, Guilhermino MM (2007) Evaluation of thermal stress indexes for dairy cows in tropical regions. Rev Bras Zootec 36:1192-1198

Somparn P, Gibb MJ, Markvichitr K, Chaiyabutr N, Thummabood S, Vajrabukka C (2004) Analysis of climatic risk for cattle and buffalo production in northeast Thailand. Int J Biometeorol 49:59-64. https://doi.org/10.1007/s00484-004-0206-6

Stephenson TS, Vincent LA, Allen T, Van Meerbeeeck CJ, McLean N, Peterson TC, Taylor MA, Aaron-Morrison AP, Auguste T, Bernard D, Boekhoudt JRI, Blenman RC, Braithwaite GC, Brown G, Butler M, Cumberbatch CJM, Etienne-Leblanc S, Lake DE, Martin DE, McDonald JL, Zaruela MO, Porter AO, Ramirez MS, Tamar GA, Roberts BA, Mitro SS, Shaw A, Spence, JM, Winder A, Trotman AR (2014) Changes in extreme temperature and precipitation in the Caribbean region, 1961-2010. Int J Climatol 34:2957-2971. doi: https://doi.org/10.1002/joc.3889

Stull R (2011) Wet-bulb temperature from relative humidity and air temperature. J Appl Meteor Climatol 50:2267-2269. https://doi.org/10. 1175/JAMC-D-11-0143.1

Tao X, Xin H (2003) Acute synergistic effects of air temperature, humidity, and velocity on homeostasis of market-size broilers. Trans ASAE 46:491-497. https://doi.org/10.13031/2013.12971

Taylor MA, Centella A, Charlery J, Bezanilla A, Campbell J, Borrajero I, Stephenson T, Nurmohamed R (2013) The PRECIS-Caribbean story: lessons and legacies. Bull Amer Meteor Soc 94:1065-1073. https://doi.org/10.1175/BAMS-D-11-00235

Taylor MA, Clarke LA, Centella A, Bezanilla A, Stephenson TS, Jones JJ, Campbell JD, Vichot A, Charlery J (2018) Future Caribbean climates in a world of rising temperatures: the $1.5 \mathrm{vs}$ 2.0 dilemma. Submitted to Journal for Regional Environmental Change. https://doi.org/10.1175/JCLI-D-17-0074.1

Whittier JC (1993) Hot weather livestock stress. G2099 University of Missouri Extension Pub. http://extension.missouri.edu/p/G2099\# guide., Accessed 21 July 2017

Zulovich JM, DeShazer JA (1990) Estimating egg production declines at high environmental temperatures and humidity. ASAE Paper No. 904021, American Society of Agricultural Engineers, St. Joseph, MI, USA

Zumbach B, Misztal I, Tsuruta S, Sanchez JP, Azain M, Herring W, Holl J, Long T, Culbertson M (2008) Genetic component of heat stress in finishing pigs: development of a heat load function. J Anim Sci 86: 2082-2088. https://doi.org/10.2527/jas.2007-0523 